\title{
The Relationship Between Postsecondary Education and Skill: Comparing Credentialism with Human Capital Theory
}

\section{DAVID WALTERS}

Brock University

\section{ABSTRACT}

This paper assesses the importance of the credential requirements used by employers to attract graduates who will use their education on the job. The framework of this study is embedded within the theoretical debates between proponents of the credentialist and human capital theories of education. Past research related to these debates has focused largely on issues such as earnings, underemployment, and productivity, while less empirical treatment has focused on the issue of skill utilization. The statistical analysis suggests that there is a strong correspondence between employees' credentials and the needs of their employers. The extent to which the viability of each theoretical position depends on specific postsecondary programs is also explored. 


\section{RÉSUMÉ}

Cet article se penche sur l'importance des lettres de créance exigées par les employeurs pour attirer les étudiants gradués qui feront usage de leurs compétences sur le marché du travail. Il s'inscrit dans le débat théorique opposant les tenants de l'approche "crédentialiste" et ceux de la théorie du capital humain en éducation. La plupart des études à caractère empirique ont insisté jusqu'à maintenant sur des thèmes comme le revenu, le sous-emploi et la productivité, alors que les études théoriques se sont davantage intéressés à l'utilisation des compétences. L'analyse statistique présentée ici suggère une correspondance marquée entre les références des employés et les besoins de leurs employeurs. Nous analysons également le lien entre les approches traitées et le programme d'études post-secondaire auquel elles s'adressent.

\section{INTRODUCTION}

As more and more employers are demanding postsecondary credentials for basic entry-level positions, many investigators are deeply concerned about whether postsecondary credentials are actually needed in the contemporary labour market. Does a postsecondary education provide students with the skills that they need in order to be successful? Or does it simply supply educational credentials? More specifically, does postsecondary education teach the skills needed for specific professional occupations, or does it merely provide them with a slight advantage when competing for jobs that could be performed with a lower level of schooling?

Drawing on a large Canadian dataset, this study assesses whether the credentials requested by employers are useful, in terms 
of obtaining graduates with the appropriate skills for their jobs. This paper is also intended to inform the theoretical debates in this area, as much of the discussion and analysis is organized around human capital and credentialist approaches. They are the two most fruitful approaches available to analyze the transitions from school to work; however, there is little empirical evidence available that would enable the propositions of each theory to be tested. The relevant theoretical issues are discussed briefly below.

\section{THEORETICAL CONTEXT}

\section{Functionalism and Human Capital Theory}

The idea that the expansion of postsecondary education systems in developed countries after World War II was the consequence of industrialization is associated with the sociological functionalist approach. According to functionalist theory, economic and technological innovation generally raises the skill levels required to perform jobs. At the same time, manual labour jobs disappear as new knowledge-based jobs grow and the need for new knowledge increases within existing occupations. Thus, formal educational institutions must expand in order for individuals to learn the skills required for the more complex jobs (Rubinson \& Browne, 1994, p. 585). The technical functional theory also asserts that education responds to industrial and economic growth. That is, educational institutions themselves become creators of new technologies and information, thereby increasing the complexity of jobs and sustaining educational growth.

The human capital theory of education is an economic variant of the technical functional theory. The fundamental postulate of human capital theory (Becker, 1964; Schultz, 1961) ${ }^{1}$ is that increases in schooling are responses to an increased demand for skilled labour. Thus, individuals will continue to pursue higher levels of education 
until the opportunity cost of acquiring more education is greater than the benefit that it provides. Attention was first directed to human capital as economists began to realize that the growth of physical capital does not explain much of the income growth in most countries (Becker, 1964). Earlier theoretical developments in economics suggested that it was necessary for a nation to have plenty of natural resources in order to develop a modern economy. However, following the rise of Japan as a world economic leader, despite its obvious lack of natural resources; it became quite apparent that resourceful land and an abundance of physical capital is insufficient to explain modern economic growth (Schultz, 1971).

Education is a form of human capital that has been most widely discussed in the literature. ${ }^{2}$ Proponents of human capital theory assert that schools were developed to prepare people for modern roles that are not addressed by the more traditional agents of socialization, such as the family or the church. Education is assumed to provide students with skills they can bring to their jobs, and it also allows them to be more productive and functional members of society. Education represents a major means through which individuals acquire the mental skills and capacities for self-direction necessary for successful future performance in the workplace (Hunter, 1988). It also encourages higher levels of competence and socializes students into modern tastes and values. Those with limited amounts of education enter the labour force destined to remain in lower level jobs because they lack the skills required to be successful. Indeed, the relative labour market advantages of higher educated workers is a major reason why so many youth continue to pursue advanced levels of education.

Most of the North American academic literature and policy research in the area before the 1970s was grounded in the human capital model and painted a glowing picture of the relationship 
between education and economic growth (Fuller \& Rubinson, 1992, p. 121). From the 1950 s to the 1970 s, human capital theory helped to shape the thinking of policy makers and to a considerable extent was responsible for the expansion of schooling (Ashton \& Lowe, 1991, p. 65).

However, the viability of human capital theory was first seriously questioned in the early 1970s, particularly following Braverman's (1974) assertion that the importance of education for job success at varying skill and autonomy levels had declined. Since then, many have challenged the human capital argument that education generates skills and increases productivity (Livingstone, 1998; Wolf, 2002). ${ }^{3}$ In fact, David Livingstone maintains that most of the net skill upgrading of jobs' since the 1940s had occurred before the 1960s. He also argues that most human capital and post-industrial/ knowledge-based economy theorists have exaggerated the extent of skill upgrading (Livingstone, 1998, pp. 147-148).

\section{Credentialism}

Most of the discontent with human capital theory stems not so much from the methodological problems and the inconsistent empirical evidence, but rather with the emergence of new, more critical, theoretical perspectives within the sociology of education (Rubinson \& Browne, 1994, p. 585). It has been argued that "sociological research on earnings has evolved largely in reaction to the human capital model of economics" (Halaby \& Weakliem, 1993, p. 16). Human capital theory has been challenged on a number of grounds. First, it is limited because it does not adequately address the fact that those from upper classes benefit (Bowles \& Gintis, 1976). Second, it also has been challenged for not dealing with social and structural arrangements, which, along with individual factors, are responsible for the reproduction of inequality (Smith, 1990). Third, 
human capital theory is also criticized because it does not devote enough attention to the fact that some people are socially and culturally better prepared to gain access and succeed within the education system than others (Bernstein, 1973). Fourth, human capital theory is questioned because it provides little insight into why different postsecondary programs (degrees) are correlated with particular jobs rather than "years of schooling" (Brown, 1995, p. 30).

However, the most telling theoretical challenge to human capital theory within sociology comes from the proponents of the credentialist perspective; theorists who take immediate issue with the argument that education produces the necessary skills to be successful in a contemporary labour market. Ivar Berg (1970) was one of the first credentialist theorists to challenge the prevailing argument that industrial economies need even higher proportions of highly educated workers. However, it was Randall Collins' (1979) influential work on the "credential society" that has become the hallmark of what is known as the credentialist theory. Collins, like Berg, disagreed with the functionalist assertion that technological change requires constant skill upgrading and an expanding education system. According to Collins (1979), there is a weak connection, at best, between formal educational credentials and skills required on the job. He maintained that what is learned in school has much more to do with conventional standards of sociability and propriety than with instrumental and cognitive skills (Collins, 1979, p. 19). He also argued that the value of any kind of education depends less and less on specific content and more and more on having attained a given level and having acquired the formal credential that allows one to enter the next level (Collins, 1979, p. 93). One of Collins' central claims is that the "rise of a competitive system for producing abstract cultural currency in the form of educational credentials has 
been the major new force shaping stratification in twentieth-century America" (Collins, 1979, p. 94).

Essentially, Collins' (1979) credentialist position was that employers were using credentials to allocate more educated workers to better jobs, and that more highly educated workers were finding more lucrative jobs, not necessarily because they were more skilled or productive, but simply because they had more education. He felt that as long as employers continued to allocate better jobs to more highly educated people, there would be increased pressure for the system to provide better-educated workers, regardless of the skill requirements of the job. Collins believed that educational credentials had become the currency for employment and that students were expected to attain a sufficient amount of this "artificial good" in order to obtain respectable positions (Collins, 1979, p. 183). He also maintained that education would allow people to purchase more desirable occupational positions, while at the same time, those in elite occupations were able to control the requirements for admission to specific professional programs in such a way as to maintain their dominant status.

There is a wealth of empirical evidence to assess the viability of the human capital and credentialist perspectives. Most of the empirical support for human capital theory comes from within economics (Rubinson \& Browne, 1994, p. 583). However, some direct and indirect evidence in favour of human capital theory has been obtained by sociologists (Hunter, 1988; Paju, 1997). For the most part, the strongest support for human capital theory comes from individual-level statistical evidence, which suggests that the most educated and skilled people almost always earn more than others. ${ }^{4}$ Some findings from aggregate level data, on the other hand, have been less favourable (Wolf, 2002). Indeed, many believe that the continued support for human capital arguments, that education 
produces skills and increases productivity, is believed by many to be based largely on faith rather than on empirical evidence (Collins, 1979, p. 15; Livingstone, 1998, p. 163; Meyer, 1977).

Empirical support for the credentialist perspective is found in the wealth of statistical evidence suggesting that the returns on postsecondary education are declining (Livingstone, 1998; see also Smith, (1996) for an earlier review). In fact, a major concern among many proponents of the credentialist perspective is that higher education no longer guarantees a respectable job, and that educational expansion has, for the most part, only served to increase the underemployment levels of postsecondary graduates. ${ }^{5}$ The overqualification of workers is considered a major social phenomenon, and viewed as a major challenge to human capital theory (Livingstone, 1998, p. 167).

Unfortunately, there is not enough evidence currently available to allow us to adequately test the merits of each theory with respect to skill utilization. Therefore, this study is able to make a contribution to the research literature by addressing theoretical questions, which to this point have not been thoroughly tested. The statistical analysis will test the human capital and credentialist perspectives by using an independent variable that assesses whether the respondents' credentials were requested for their jobs, and a dependent variable that assesses whether their education is related to their work. Since human capital theory asserts that postsecondary schooling generates the skills that are later used on the job, support for this theory would be obtained if employers' requests for specific credentials are useful for obtaining graduates who use their education on the job. On the other hand, the results would support the credentialist position if employers' requests for postsecondary credentials as a job requirement are not useful for attracting graduates who will later use their education on the job. Furthermore, by distinguishing among 
various postsecondary programs instead of simply using "years of schooling" to assess educational attainment, it is possible to identify the applicability of human capital and credentialist perspectives to various postsecondary programs.

\section{DATA AND METHODS}

The data are taken from Statistics Canada's National Graduates Survey (NGS). The NGS provides information about the link between educational experiences and employment outcomes and the rate of return on investment in human capital. The usable sample for the NGS is 43,040 cases, representing all provinces and territories. It is the largest survey available in Canada to document the schoolto-work transitions.

The 1995 NGS was developed in 1996, plans and interview questions were tested in early 1997, and the actual survey was administered between May and July of 1997, two years following the respondents' graduation. The survey was conducted by telephone, and respondents were asked a variety of questions relating to their educational histories and employment situations. The base population of the NGS is all graduates from Canadian postsecondary educational institutions who have completed the requirements for degrees, diplomas, or certificates during the calendar year for which the survey was planned. The three levels of postsecondary institutions included in the population are universities, colleges, and technical institutions. University programs lead to a bachelor's, master's, or a doctorate degree. Programs of community colleges and similar institutions are generally at least one year in duration, and normally require a secondary school diploma or equivalent for admission. Skilled trades programs have less stringent admission requirements, and are approximately three months or more in duration. The sample does not include individuals who took part-time trade courses while 
employed full-time, or people who completed vocational programs lasting less than three months.

This analysis includes those who have not obtained an additional degree, diploma, orcertificate subsequent totheoneoriginally received in 1995. Graduates who had obtained additional qualifications were excluded because they no longer belong to the original educational set of graduates. The analysis also excludes those who are working part-time because they are continuing their education. Lastly, this study is restricted only to paid workers because the key independent variable is applicable only to paid workers. ${ }^{6}$

While the results of this study are based on Canadian data, they are potentially relevant to other countries, particularly the United Kingdom and the United States. Past studies show that all three countries display similar employment trajectories (Castells \& Aoyma, 1994; Esping-Anderson, 1990). ${ }^{7}$ Also, based on a recent review of the literature in this area, Hughes and Lowe (2000) suggest that the relationship between training and work is highly consistent among all three countries. Moreover, it has also been argued the phenomenon of underemployment in the United States and Canada is comparable (Livingstone, 1998, p. 95).

\section{Variables}

The sociodemographic independent variables included in this analysis are sex, marital status, age, region, language, mother's education, father's education, Indian status, and the presence of dependent children. Information regarding the coding of these variables can be found in the Appendix. The NGS also includes two key variables that tap into the qualitative dimensions of postsecondary schooling. For the first variable, respondents were grouped according to six levels of postsecondary schooling: (1) Trade or vocational certificate; (2) College diploma or certificate; (3) Bachelor's degree; (4) Master's degree (e.g., M.A., M.Sc., M.Ed.); 
(5) Degree in medicine (M.D.), dentistry (D.D.S., DM.D.), veterinary medicine (D.V.M.), law (LLB); optometry (O.D.), theology (M.Div); and (6) Earned doctorate (e.g. Ph.D., D.Sc., D.Ed.). While a higher score generally implies a higher level of schooling, this variable will be treated as categorical considering the discrete nature of the categories.

The respondents were also asked to report their field of study. Their responses were then converted by Statistics Canada into a five-digit field-of-study code. These field-of-study codes were then aggregated by Statistics Canada into a smaller subset of ten categories, using a harmonization code which matches the university student field of study codes (USIS) and the community college and trade-vocational field of study codes (CCSIS) to census field of study codes. The census field-of-study codes are applicable for all graduates. They were designed so that the NGS findings could be compared with those of other Statistics Canada surveys and the Census of Population (see Appendix B of the 1995 NGS). The harmonized categories are grouped according to the following fields of study:

1. Education, recreational, and counseling services;

2. Fine and applied arts;

3. Humanities and related fields;

4. Social sciences and related fields;

5. Commerce, management, and business administration;

6. Agricultural and biological sciences;

7. Engineering and applied sciences, technologies, and trades;

8. Health professions, sciences, and technologies;

9. Mathematics and physical sciences; and

10. Interdisciplinary studies, unknown, or other.

As well, two occupation variables were included in the analysis. The first variable distinguishes between those who work fulltime, and those who work part-time. The second variable is used to assess the respondent's occupation and is based on the Standard Occupational Classification (SOC) used by Statistics Canada. 
The key independent variable in this analysis is a variable that captures the extent to which respondents' qualifications match the educational requirements of their jobs. This variable was derived by the researcher using several questions available in the NGS. The first question asks the respondents: "When you were selected for your job, what level of education was needed to get the job?" The second question asks: "Did the employer specify that it must be a specific field of study?" (yes/no). The third question asks the respondents to identify the field. The derived variable has three categories: (1) No education was required for the job; (2) Postsecondary education was requested, but not in a particular area of study; and (3) Postsecondary education was requested in a specific field which matched the respondent's field. This variable is used in the analysis to determine whether respondents in jobs that require a postsecondary degree or diploma are more likely to report a fit between their education and their work (dependent variable discussed directly below) than respondents in jobs that do not require a postsecondary credential, or those in jobs that require a credential, but not from a specific field of study.

\section{Dependent Variable}

The dependent variable is a self-reported assessment of the extent to which respondents' feel that their job is related to their schooling. The response options for this variable are: (1) closely related, (2) somewhat related, and (3) not at all related. In the past, most studies obtained subjective information on the underutilization of skills by surveying employers, while much less attention was given to workers' evaluations of the usefulness of their education and training (Betcherman, 1993; Lowe \& Krahn, 1995, pp. 363, 370). However, it has been argued that researchers should devote more attention to the actual experiences of graduates because they are capable of assessing whether the training they received is, or is not, being utilized on the job (Lowe \& Krahn, 1995, p. 364). It is believed that using 
employees' assessments to evaluate the usefulness of their education can provide a valuable contribution to the research literature because these assessments tap into the reality of the respondent (Lowe \& Krahn, 1995, p. 363; Rumberger, 1986). ${ }^{8}$

While subjective evaluations used to assess the correspondence between education and work are subject to criticism, they are extremely valuable when it is not possible to obtain information using an objective approach. Unfortunately, there is no objective measure available to assess a correspondence between the skills obtained at postsecondary institutions and those demanded on the job. In particular, objective measures of skill utilization such as the General Economic Development scores (GED) are of limited use to researchers who wish to assess the correspondence between education and skill utilization among different types of postsecondary graduates.?

The use of self-reported questions to assess the matching between education and work is also grounded in the assumption that respondents are just as able to decide whether their education is related to their jobs as any objective or external measures. Unfortunately, there is little research available to assess the validity and reliability of these measures (Krahn \& Lowe, 1998, p. 8). However, the self-reported measure used in this study appears to provide adequate face validity; that is this variable seems to measure what it is intended to measure. ${ }^{10}$

\section{RESULTS}

Since the dependent variable has three, relatively discrete, but ordered categories, ordered logistic regression was used for the statistical analysis." ${ }^{11}$ Two models were estimated in total. Model 1 includes the education variables field of study and level of schooling. ${ }^{12}$ Model 2 also includes the matching variable, which represents whether a postsecondary education from a specific field of study was required for the respondent's job. ${ }^{13}$ As mentioned above, this variable is included so that it can be determined whether 


\section{Table 1}

\section{Ordered Logistic Regression}

Dependent Variable: Whether Education is Related to Job

I = closely related, 2 = somewhat related, 3 = not at all related

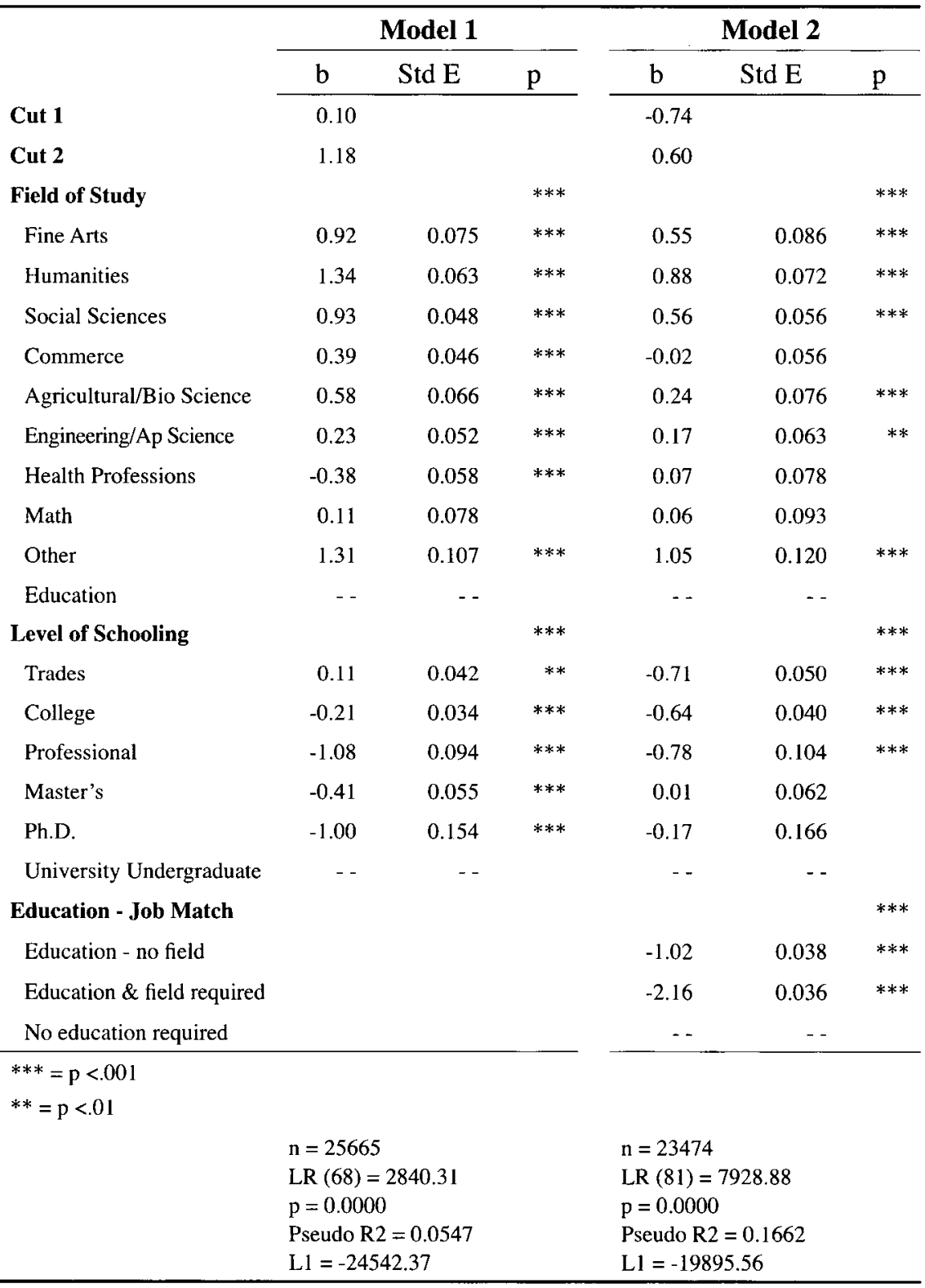


the request for a specific postsecondary credential by the employer is justified, at least according to the respondents' perceptions regarding whether their education is actually being utilized on the job. The model statistics and parameter estimates are found in Table 1.

In order to make the results more easily interpretable, the coefficients for the education variables are converted into predicted probabilities and plotted in Figures 1 and $2 .{ }^{141516}$ Figure 1 shows the predicted probabilities for level of schooling.

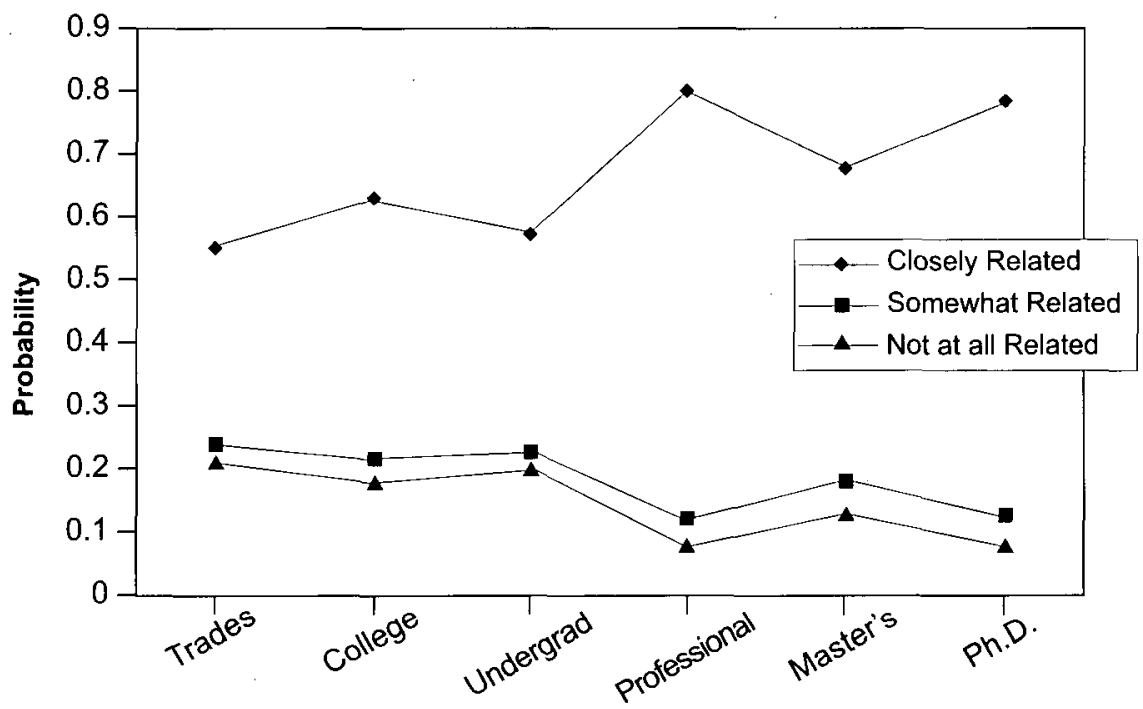

Figure 1. Education-Job-Match by Level of Schooling

Control variables include: Sex, marital status, Indian status, region, mother's and father's education, number of children, language of interview, and age.

Graduates of professional programs are clearly the most likely to feel that they are in jobs that are related to their schooling. They have a predicted probability of .80 of feeling that they are in jobs that are closely related to their schooling, while their respective probabilities of feeling that they are in jobs that are somewhat or unrelated to their education are .12 and .08. Right behind them are Ph.D. graduates, 
who have a predicted probability of .79 of feeling that their jobs are closely related to their education. Their probabilities of feeling that their jobs are somewhat or unrelated to their education are .13 and .08 , respectively.

Master's graduates have a slightly lower predicted probability of feeling that their jobs are closely related to their education (.68), and their respective probabilities of feeling that their jobs are somewhat or unrelated to their education are .19 and .14 .

Community college graduates are slightly less likely to feel that their jobs are closely related to their schooling. They have a predicted probability of .63 of feeling like their jobs are closely related to their schooling, and probabilities of .21 and .17 of feeling that they are in jobs that are somewhat related or not at all related to their schooling. The probability that university undergraduates (i.e., graduates of full undergraduate degree programs) find themselves in jobs that they feel are closely related to their schooling is .58. Their probabilities of being in positions that they feel to be somewhat or unrelated to their schooling are .22 and .20 , respectively.

Lastly, trades graduates are the least likely of all postsecondary graduates to feel that their education is related to their job (.55). Conversely, they are the most likely to feel that their education is somewhat related $(.23)$ or unrelated $(.22)$ to their jobs.

Figure 2 displays the predicted probabilities for field of study. The results show that graduates of the humanities and the "other" programs have the highest probability of feeling that they are in jobs that are unrelated to their schooling. Social science and fine arts graduates are next; their probabilities of being in jobs related to their schooling are identical. Graduates of the agricultural and biological sciences programs have slightly better chances of being in jobs related to their schooling. The probability that they feel that they are in jobs closely related, somewhat related, or unrelated to their schooling is $.57, .23$, and .20 respectively. The probability that 
commerce graduates will find themselves in jobs closely related to their schooling is .61 , while their respective probabilities of being in jobs somewhat related or unrelated to their schooling are .21 and .18.

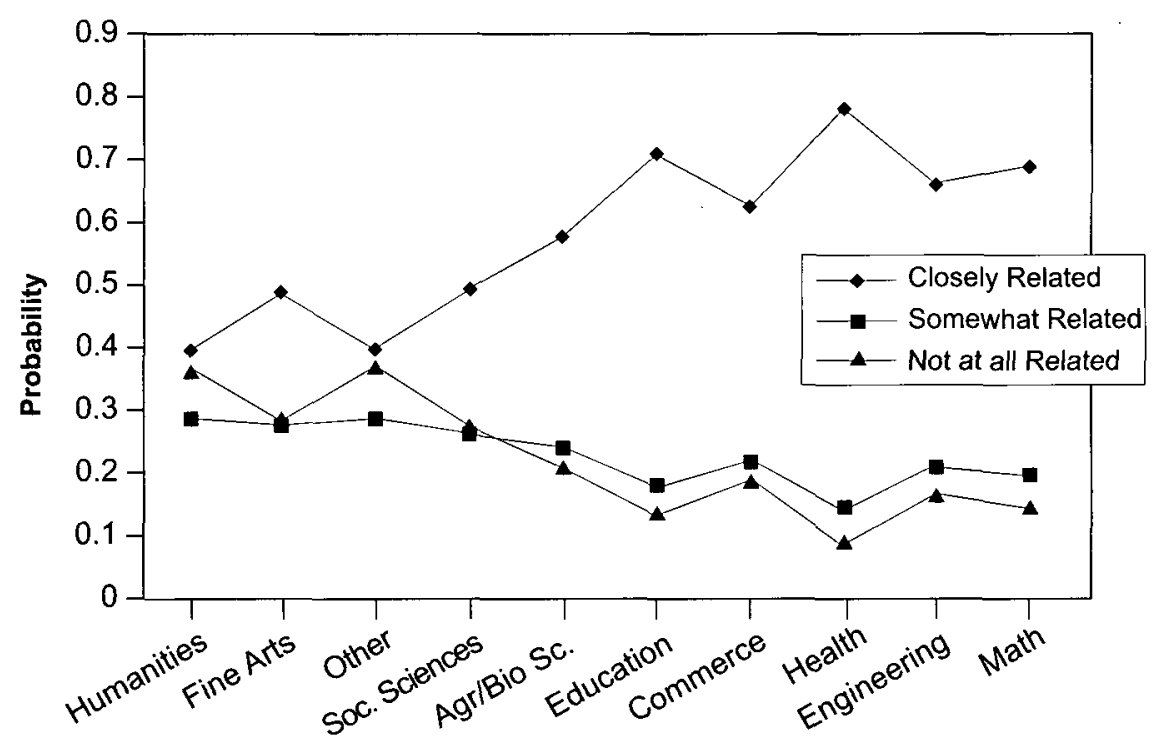

Figure 2. Education-Job-Match by Field of Study

Control variables include: Sex, marital status, Indian status, region, mother's and father's education, number of children, language of interview, and age.

Engineering and mathematics graduates have an even greater probability of feeling that they are in jobs that are closely related to their work than do commerce graduates. Education graduates, the reference category, have a probability of being employed in jobs that they feel to be closely related to their schooling of .70. Their probability of being in jobs that are somewhat related and unrelated to their schooling is .17 and .13 , respectively.

Graduates of the health programs clearly have the greatest chance of being employed in jobs related to their schooling. The probability that these graduates will find a job closely related to their schooling 
is .77. Their respective probabilities of finding themselves in jobs they feel to be somewhat related or unrelated are .14 and .09 .

Model 2 includes the parameter estimates for the variable that identifies whether graduates are in jobs that require their postsecondary credentials. The parameter estimates for this variable are converted into the predicted probabilities, and plotted in Figure 3. ${ }^{17}$

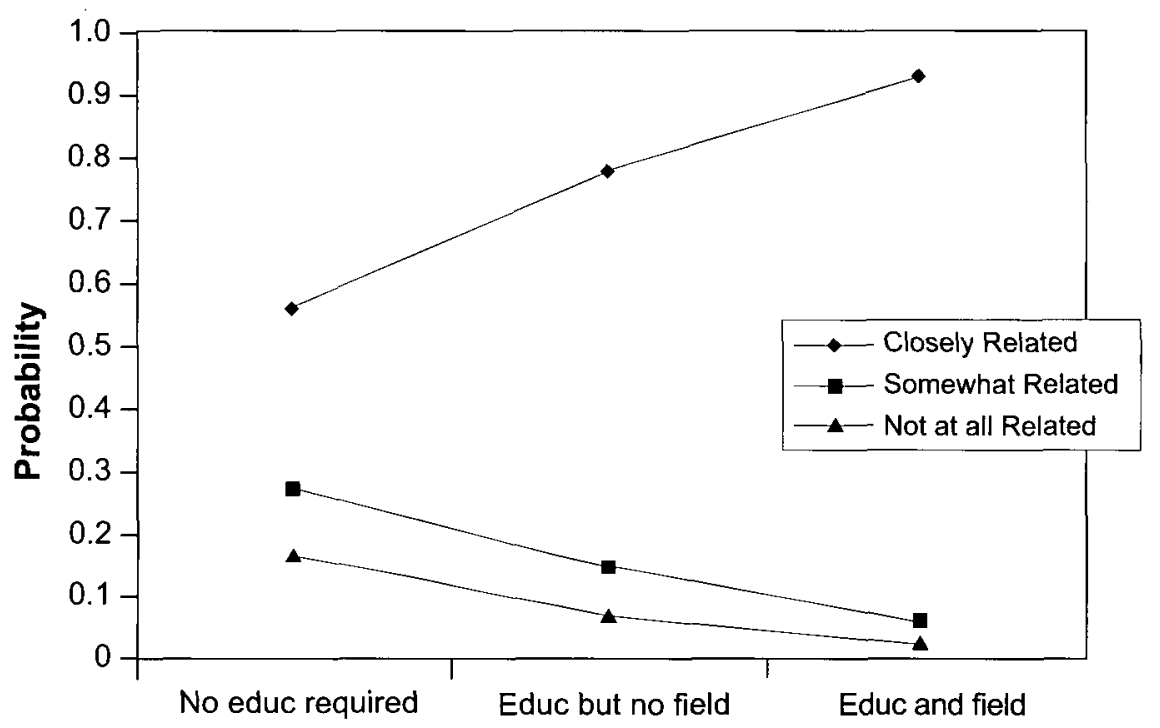

Whether Education is Required for Job

\section{Figure 3. Fit Between Education and Work}

Control variables include: Sex, marital status, Indian status, region, mother's and father's education, number of children, language of interview, and age.

As can be seen in the figure, graduates who find themselves in jobs that require a postsecondary credential in their particular field of study have the highest probability of finding themselves in jobs that are directly related to their education (.92) and the lowest probability of being in jobs they feel are somewhat related (.06) and not at all related (.02). Graduates whose employers requested a postsecondary credential, but not in a specific area, also have a high probability 
(.78) of being employed in jobs that they feel to be directly related to their education. Their respective probabilities of being employed in jobs they feel are somewhat related and unrelated to their education are .15 and .07 . For graduates in jobs where the employer does not request a postsecondary credential, the probability of feeling like one's job is closely related to her/his education is relatively low in comparison (.56). Conversely, their chances of finding themselves in jobs only somewhat related or unrelated to their work are .27 and .17 , respectively.

\section{DISCUSSION AND CONCLUSIONS}

Before addressing the results, there is one key limitation related to the data that should be mentioned. Specifically, there are a number of variables that could not be controlled in this analysis. Unfortunately, the National Graduates Survey does not contain measures of ability (i.e., standardized test scores or high school grades) or college selectivity (i.e., admission requirements). Without information related to these issues, there may be alternative explanations for the findings. In particular, the results may be subject to selection bias. Regrettably, this is a limitation of most studies involving higher education that are based on Canadian data. ${ }^{18}$ Nevertheless, the results do provide some important implications that are discussed below.

A key objective of this study was to make a contribution to the theoretical debates on a key issue relating to transitions from school to work. One of the major limitations of past studies that have evaluated the human capital and credentialist perspectives is that they focus primarily on earnings, and pay less attention to the issue of whether graduates use their education on the job. Thus, a central purpose of this paper is to build on past research in the area by exploring the fit between education and work among postsecondary graduates of various programs. 
In regard to whether postsecondary education provides graduates with credentials that are required and used in the labour market, the results provide some support for human capital theory, suggesting that there is a strong connection between postsecondary schooling and employee perceptions of the education requirements for their jobs. Postsecondary graduates with credentials that match those requested by their employers report a closer fit between their education and work than do graduates whose credentials do not directly match those recommended for their job, or graduates in jobs that do not require postsecondary credentials. Employers, therefore, appear to be in tune with their employment needs, as they are using education credentials to appropriately channel those with relevant skills sets into suitable jobs. This implies, contrary to what the credentialist theory might suggest, that the educational qualifications recommended by employers are justified in terms of matching the qualifications of graduates with the needs of employers, at least when one examines the subjective feelings of the respondents.

On the other hand, the results also show that there are a large number of graduates, particularly those of liberal arts programs, who are in jobs that are not related to their schooling. This finding lends support for the credentialist perspective, that there is widespread mismatching of credentials in the labour market, leaving the talents of many educated people underutilized during the early stages of their transition from school to work.

In comparison with graduates of community college and university programs, graduates of trades programs are least likely to feel that their jobs are related to their educational training. This is somewhat surprising as one might expect these graduates to report a very close correspondence between their schooling and their occupational outcomes (i.e., a mechanic certificate program should provide a ticket for a job as a mechanic). This finding should be interesting to individuals involved in making policy decisions regarding trades institutions. Clearly, more effort should be made to 
help these institutions be more effective in terms of channeling their graduates into jobs that require their particular training.

The results of this study also potentially suggest that the viability of the human capital and credentialist positions depend largely on qualitative differences that exist at the postsecondary level. For example, human capital theory might be more applicable to the applied and technical programs, since liberal arts graduates are most likely to feel that they utilize their schooling on the job. Conversely, the credentalist perspective appears to be more applicable to a liberal arts postsecondary education, since these graduates are least likely to feel that what they learned in school is relevant to their work. However, caution must be taken before drawing this conclusion, since the dependent variable is a subjective measure of the fit between education and work. Therefore, there may be an issue as to whether the question is equally valid for graduates of general arts and science programs (Krahn \& Lowe, 1998, p. 8). For example, this question may be more applicable to graduates of technical programs where the subject matter is more directly oriented to the labour market. Likewise, graduates of liberal arts programs may be unaware of other skills that that they have developed in order to achieve the degree (i.e., writing skills, research skills, presentation skills, time management skills, team-work skills, etc.) that may be very applicable to their job, but difficult to capture with one question. Thus, more definitive conclusions on this issue can only be made once measures, which tap into the correspondence between education and work, are better established in terms of validity and reliability.

Nonetheless, the results provide a preliminary indication that the value of each theoretical perspective may be specific to certain postsecondary programs, which may have implications for future research and theoretical development in the area. For example, while the importance of addressing the qualitative dimensions of postsecondary schooling (i.e., field of study) has received a growing amount of attention in the research literature (Axelrod, Anisef, 
\& Lin, 2001; Butlin, 2001; Davies \& Guppy, 1997; Davies \& Hammack, 2004; Finnie, 2001; Hay, 2000; Jacobs, 1995; Krahn \& Lowe, 1998; Walters, 2003, 2004), past studies which have informed the theoretical debates in the area have generally treated education primarily as a quantitative variable, in terms of years of schooling. However, the results of this study suggest that future theoretical development would be better informed by emphasizing how the credentialing process operates for graduates of different types of postsecondary schooling. Hopefully, this study will cause researchers to consider the qualitative dimensions of postsecondary schooling in their theoretically informed research on the transitions from school to work. 


\section{Notes}

${ }^{1}$ Human capital theory is usually attributed to economists G. Becker (1964) and T.W. Schultz (1961). However, Jacob Mincer (1958) is considered to be one of the original pioneers of human capital approach (Becker, 1964), and the principles of human capital theory can be recognized in the earlier work of Alfred Marshall and Adam Smith.

${ }^{2}$ Other forms of human capital include: job training, migration, health, and economic information (Schultz, 1971).

${ }^{3}$ While human capitalist theorists argue that education generates skills, others assert that education serves as a mechanism whereby preexisting skills are identified (Taubman \& Wales, 1974).

${ }^{4}$ However, the signaling hypothesis represents a major competing explanation (to human capital theory) regarding why graduates with higher levels of education earn more than those with less schooling.

${ }^{5}$ Another major concern is that the goals of the education system have been transformed to the service of private rather than public interests, while, at the same time, emphasis on learning has been devalued (Labaree, 1997). It is also argued that the education system has become inefficient, and unable to adequately train students to be productive workers or to become capable citizens (Brown, 1995).

${ }^{6}$ The question used to ascertain whether a postsecondary credential was required for the respondent's job does not apply to self-employed workers.

${ }^{7}$ As well, Guppy and Davies (1998) have provided a brief discussion of the similarities between education systems in Canada and the United States, while Ashton and Lowe (1991) provide a review of the similarities between postsecondary schooling in Canada and Britain.

${ }^{8}$ However, others perceive this as a disadvantage of subjective approaches (Clogg \& Shockey, 1984).

${ }^{9}$ The method used by Clogg and Shockey (1984) is limited for the same reason. It is not useful for making comparisons among postsecondary graduates of various fields of study.

${ }^{10}$ There is an issue as to whether "objective" and "subjective" assessments of job characteristics are better or even different (Myles \& Fawcett, 1990). 
However, Redpath (1994, pp. 96-97) has shown that employees' perceptions of skill-utilization are accurate reflections of more objective measures.

${ }^{11}$ In some instances, even when the dependent variable is ordered, it may be more appropriate to use a multinomial logistic regression model (Long, 1997, p. 115). Therefore, as a precautionary measure, models were estimated using both ordered and multinomial logistic regression models, and the Bayesian Information Criterion (BIC) statistic was used to compare the fit of each model (the model with a smaller BIC is better fitting). The BIC fit statistic is appropriate for such comparisons because it makes an adjustment for sample size. After comparing the BIC statistics that were generated for each model, it was determined that there was relatively little difference between the two models. (The BIC for the ordered logit model is 51171 , whereas the BIC for the multinomial logistic regression model is 51202.) As a smaller BIC indicates a better fit, the more parsimonious ordered logit model was used.

${ }^{12}$ The independent sociodemographic variables gender, age, marital status, region, language of interview, Indian status, number of children, mother's education, father's education are controlled in both models. The coefficients for these variables are available from the author by request.

${ }^{13}$ This model also includes two additional variables for occupational status. Since these variables are not central to this study, they are not discussed. The results pertaining to these variables are available from the author by request.

${ }^{14}$ All predicted probabilities are calculated holding the other variables constant at their means. Thus, all of the results should be interpreted as controlling for all of the other variables in the model.

${ }^{15}$ The value of -1.005 is added to the coefficients in Model 2 to produce the predicted probabilities in each of the following figures. This represents the summated value of coefficients for the control variables multiplied by the respective proportion of respondents in each category.

${ }^{16}$ See Fox (2002) for information on plotting predicted probabilities for ordered logistic regression models.

${ }^{17}$ Again, the predicted probabilities are estimated, holding the other variables at their respective means.

${ }^{18}$ In contrast to the U.S. system, Canadian postsecondary institutions generally do not require students to write the Standardized Aptitude Test. 


\section{References}

Anisef, P., \& Axelrod, P. (1993). Transitions: Schooling and employment in Canada. Toronto: University of Toronto Press.

Ashton, D., \& Lowe, G. (1991). Making their way: Education, training and the labor market in Canada and Britain. Toronto: University of Toronto Press.

Axelrod, P., Anisef, P., \& Lin, Z. (2001). Against all odds? The enduring value of liberal education in universities, professions, and the labour market. The Canadian Journal of Higher Education, 31(2), 47-78.

Becker, S. (1964). Human capital: A theoretical and empirical analysis, with special reference to education. New York: Columbia University Press.

Berg, I. (1970). Education and jobs: The great training robbery. New York: Praeger.

Bernstein, B. (1973). Class, codes and control: Volume 1. London: Routledge and Kegan Paul.

Betcherman, G. (1993). Research gaps facing training policy-makers. Canadian Public Policy, XIX(1), 18-28.

Bowles, S., \& Gintis, H. (1976). Schooling in capitalist America: Educational reform and the contradictions of economic life. New York: Basic Books.

Braverman, H. (1974). Labor and monopoly capital. New York: Monthly Review Press.

Brown, D. (1995). Degrees of control: A sociology of educational expansion and occupational credentialism. New York: Teachers College Press.

Butlin, G. (2001). Bachelor's graduates who pursue further postsecondary education. Education Quarterly Review, 7(2), 22-41.

Castells, M., \& Aoyma, Y. (1994). Paths towards the informational society: Employment structure in G-7 countries, 1920-90. International Labor Review, 133(1), 5-33.

Clogg, C.C., \& Shockey, J.W. (1984). Mismatch between occupation and schooling: A prevalence measure, recent trends and demographic analysis. Demography, 21(2), 235-257.

Collins, R. (1979). The credential society. New York: Academic Press.

Davies, S., \& Guppy, N. (1997). Fields of study, college selectivity, and student inequalities in higher education. Social Forces, 75(4), 1417-1438. 
Davies, S., \& Hammack, F. (2004). The channelling of student competition: Comparing Canada and the U.S. Journal of Higher Education. Forthcoming.

Epsing-Anderson, G. (1990). The three worlds of welfare capitalism. Cambridge: Polity Pr.

Finnie, R. (2001). Fields of plenty, fields of lean: The early labour market outcomes of Canadian university graduates by discipline. The Canadian Journal of Higher Education, 31(1), 141-176.

Fox, J. (2002). An $R$ and S-Plus companion to applied regression. California: Sage.

Fuller, B., \& Rubinson, R. (1992). The political construction of education. New York: Praegar.

Guppy, N., \& Davies, S. (1998). Education in Canada: Recent trends and future challenges. Ottawa: Statistics Canada.

Halaby C.N., \& Weakliem, D.L. (1993). Ownership and authority in the earnings function: Nonnested tests of alternative specifications. American Sociological Review, 58(1), 16-30.

Hughes, K.D., \& Lowe, G.S. (2000). Surveying the post-industrial landscape: Information technologies and labor market polarization in Canada. Canadian Review of Sociology and Anthropology, 37(1), 29-53.

Hunter, A.A. (1988). Formal education and initial employment: Unravelling the relationships between schooling and skills over time. American Sociological Review, 53(5), 753-765.

Jacobs, J. (1995). Gender and academic specialities: Trends among recipients of college degrees in the 1980s. Sociology of Education, 68(2), 81-98.

Krahn H., \& Lowe, G.S. (1998). Measuring the fit or mismatch between university education and employment outcomes. School-Work Transitions Project. Edmonton, AB.

Labaree, D. (1997). How to succeed in school without really learning. London: Yale University.

Livingstone, D.W. (1998). The education-jobs gap: Underemployment or economic democracy. Boulder, CO: Westview Press.

Long, S.J. (1997). Regression models for categorical and limited dependent variables. London: Sage Publications.

Lowe G.S., \& Krahn, H. (1995). Job-related education and training among younger workers. Canadian Public Policy, XXI(3), 362-378. 
Meyer, J. (1977). The effects of education as an institution. American Journal of Sociology, 83, 55-77.

Mincer, J. (1958). Investment in human capital and personal income distribution. Journal of Political Economy, August 1958.

Paju, M. (1997). The class of ' 90 revisited: Report of the 1995 follow-up survey of 1990 graduates. Education Quarterly Review, 4(4), 9-29.

Rubinson, R., \& Browne, I. (1994). Education and the economy. In N. Smelser \& R. Swedberg (Eds.), The handbook of economic sociology, (pp. 581-599). Princeton, NJ: Princeton University Press.

Rumberger, R.W. (1996). The impact of surplus schooling on productivity and earnings. The Journal of Human Resources, XXII(1), 24-50.

Schultz, T.W. (1961). Investment in human capital. American Economic Review, $51,1-17$.

Schultz, T.W. (1971). Investment in human capital: The role of education and research. New York: The Free Press.

Smith, H.L. (1986). Over-educated and underemployment: An agnostic review. Sociology of Education, 59, 85-99.

Smith, M.R. (1990). What is new in new structuralist analyses of earnings? American Sociological Review, 55(6), 827-841.

Taubman, P., \& Wales, T. (1974). Higher education: An investment and a screening device. New York: McGraw-Hill.

Walters, D. (2003). Recycling: The economic implications of obtaining additional postsecondary credentials at lower or equivalent levels. Canadian Review of Sociology and Anthropology 40(4), 463-480.

Walters, D. (2004). A comparison of the labour market outcomes of postsecondary graduates of various levels and fields over a four-cohort period. Canadian Journal of Sociology 29(1), 1-27.

Wolf, A. (2002). Does education matter: Myths about education and economic growth. New York: Penguin. 


\section{David Walters}

\section{Appendix}

Sociodemographic Control Variables

\begin{tabular}{ll}
\hline Sex & Father's Education* \\
- Women & - Less than high school \\
- Men & - High school \\
Marital Status & - Some postsecondary \\
- Married & - Trade \\
- Separated/Widowed/Divorced & - University \\
- Single & - Master's \\
Indian Status & - Professional \\
- Indian & - Ph.D. \\
- Non-Indian & Number of Children \\
Region & - No children \\
- Eastern Provinces & - One child \\
- Quebec & - Two children \\
- Western Provinces & - Three or more children \\
- Ontario & Language of Interview \\
Mother's Education* & • English \\
- Less than high school & - French \\
- High school & Age \\
- Some postsecondary & - 20-45 \\
- Trade & \\
- College & \\
- University & *A separate category for "Don't \\
- Master's & Know" was included in the model \\
- Professional & for the Mother's and Father's \\
- Ph.D. & education variables. \\
& \\
\hline
\end{tabular}

